\title{
Regulatory interaction with the long-term insurance industry in pursuit of market stability and financial inclusion
}

\begin{tabular}{|c|c|}
\hline \multicolumn{2}{|c|}{$\begin{array}{l}\text { Authors: } \\
\text { Corne Heydenrych }{ }^{1} \\
\text { John M. Luiz }\end{array}$} \\
\hline \multicolumn{2}{|c|}{$\begin{array}{l}\text { Affiliations: } \\
{ }^{1} \text { Graduate School of Business, } \\
\text { University of Cape Town, } \\
\text { South Africa }\end{array}$} \\
\hline \multicolumn{2}{|c|}{$\begin{array}{l}{ }^{2} \text { School of Business, } \\
\text { Management and Economics, } \\
\text { University of Sussex, United } \\
\text { Kingdom }\end{array}$} \\
\hline \multicolumn{2}{|c|}{$\begin{array}{l}\text { Corresponding author: } \\
\text { John Luiz, } \\
\text { john.luiz@gsb.uct.ac.za }\end{array}$} \\
\hline \multicolumn{2}{|c|}{$\begin{array}{l}\text { Dates: } \\
\text { Received: } 25 \text { July } 2016 \\
\text { Accepted: } 26 \text { Aug. } 2017 \\
\text { Published: } 24 \text { July } 2018\end{array}$} \\
\hline \multicolumn{2}{|c|}{$\begin{array}{l}\text { How to cite this article: } \\
\text { Heydenrych, C. \& Luiz, J.M., } \\
\text { 2018, 'Regulatory interaction } \\
\text { with the long-term insurance } \\
\text { industry in pursuit of market } \\
\text { stability and financial } \\
\text { inclusion', South African } \\
\text { Journal of Business } \\
\text { Management 49(1), a9. } \\
\text { https://doi.org/10.4102/ } \\
\text { sajbm.v49i1.9 }\end{array}$} \\
\hline \multicolumn{2}{|c|}{$\begin{array}{l}\text { Copyright: } \\
\text { C 2018. The Authors. } \\
\text { Licensee: AOSIS. This w } \\
\text { is licensed under the } \\
\text { Creative Commons } \\
\text { Attribution License. }\end{array}$} \\
\hline \multicolumn{2}{|c|}{ Read online: } \\
\hline 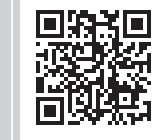 & $\begin{array}{l}\text { Scan this QR } \\
\text { code with your } \\
\text { smart phone or } \\
\text { mobile device } \\
\text { to read online. }\end{array}$ \\
\hline
\end{tabular}

This study explores how the financial regulator through interaction with the long-term insurance industry can give effect to greater market inclusion and financial stability. It follows a qualitative approach and we interview both industry representatives and the regulator. The results show that there is a possible tension between the regulatory objectives of market stability and financial inclusion and that an unbalanced focus on either objective could adversely affect the other. It suggests that the best way to ensure this balance is for industry, the regulator and government to coframe issues, rather than being obliged to rely on the regulator to draft regulation in isolation. The entry level (base of the pyramid) insurance market may require a different paradigm to 'usual' insurance constructs and this requires a more innovative approach from all stakeholders. The findings highlight strategic measures that may assist regulators in giving effect to greater market inclusion without prejudicing the stability of the market.

\section{Introduction}

The complexity of the interaction between multiple stakeholders in a market often requires the intervention of regulation to counter the effects of imbalances and imperfections. The rationale for regulation includes the need to prevent markets from failing because of an asymmetry of information between the provider of the product and the customer and to counter opportunistic behaviour that may give rise to the problem of moral hazard (Staschen 2010). However, regulation has to be considered within the political economic context of that market. To this end an understanding of regulatory policy in relation to public interest is important. Considering the effect of the recent financial crisis and the rapid evolution of financial frameworks and financial legislation, it is clear that much of these reactive interventions were aimed at avoiding future market failure. Although the rationale for regulation is to pursue stability and to protect markets from failing, financial markets in particular place emphasis on public interest theory (Pistor 2012). This proposes that regulation is supplied in response to the demand of the public for the correction of inefficient or inequitable market practices. The concept of regulatory policy approaches public interest not only from a defensive position but also considers a paradigm where alignment between political and economic objectives and behaviour is encouraged and rewarded. For this reason the regulator's objectives include a performative element of promoting social welfare or promoting the internalisation of normative behaviour of those regulated (Etienne 2010).

An example of the promotion of social welfare by the regulator is the desire to improve access to the market. In a financial context, the quest for greater financial inclusion has been receiving global attention through the G20 and World Bank (2015). Financial exclusion remains a social and economic concern, with many countries reflecting a formal account penetration by adults lower than $50 \%$. Globally, 2.5 billion adults do not have an account at a financial institution, with most of these residing in developing countries (Demirgüç-Kunt \& Klapper 2013:289).

Financial inclusion and regulation to stabilise markets might appear as a trade-off, but research shows that greater financial inclusion may enhance the stability of the financial market through increased fairness, efficiency and transparency (Hannig \& Jansen 2010). Considering the regulatory objective to achieve greater access to financial services, the relationship between institutions responsible for bringing the products to market and the regulator is relevant. As markets change and regulations increase, it may provide significant opportunities and threats to the industry. This requires a response from the business in terms of the regulator's changing requirements (Veal \& Mouzas 2011). To ensure an effective interaction between the regulator and the industry, the 
industry needs to be proactive. They need to understand the intentions of the regulator and shape the rules in their networks accordingly (Veal \& Mouzas 2011).

This article examines how a financial regulator through interaction with the long-term insurance industry can give effect to greater market inclusion and financial stability in South Africa. It analyses the potential conflict between the regulator's objective of greater market stability and its objective of promoting access, as well as what the most effective means of interaction is between the regulator and the industry. Although the research is exploratory in nature and was undertaken in the context of financial services, there may be general applicability in similar regulated and utility markets.

\section{Literature review}

'Regulation' typically refers to a collective of rules, directives and legislation, combined with the power of a regulator to monitor compliance. It is accepted that the general purpose of regulation of any market lies within the concept of control. Control does not denote market power of a regulator with reference to its industry but rather refers to the application of prescribed rules, procedures or principles to avoid market failure and to protect the end consumer.

In terms of game theory, where one party (the firm) acts as an agent or representative in the market on behalf of its principal (the end customer), it is reasonable to deduce that, irrespective of their agency relationship, both parties may attempt to maximise their respective utilities or self-interests, resulting in the agent not always acting in the best interest of its principal (Laffont \& Martimort 2009). The utility function and the relative position of wealth and power of the agent and principal will dictate the degree and breadth of regulation required. In such instances the role of the state is to govern the asymmetry of information (and accompanied power imbalances), not necessarily in an attempt to bring forth a perfect equilibrium between the principal and agent but to offset the gains that the agent may obtain at the cost of the principal against a particular regulatory incentive for the agent to uphold such regulation, such as rewarding the agent for particular actions or sanctioning penalties for others. Firms have better information about opportunities and risks than their individual clients because of the fact that it is expensive for clients to attain the same level of information, and thus firms can behave opportunistically, giving rise to the problem of moral hazard (Staschen 2010).

Linked to the phenomenon of imperfect markets are monopolies and oligopolies. These lead to inefficient outcomes because these markets are not competitive. In a monopolistic regime normal market forces that would regulate the quantity of a product and its price do not exist (Basso, Figueroa \& Vasquez 2016), requiring a regulator to either set price limits or determine the quantity of a product supplied. Kearney and Merrill (1998) state that the trend towards the end of the 20th century was that the role of regulators moved away from complete pervasive control to that of regulating firms horizontally and setting regulation to maximise competition between firms, based on the assumption that competition in itself may to a large degree be sufficient to protect the end user. Regulation therefore moved in the direction of not only the vertical prescription of government interests and aligning the behaviour of industries in accordance with these views but also into the private sector to ensure that competition between firms was maximised to avoid monopolistic behaviour. Thus the objectives for regulation, within the context of public interest theory, can be summarised as follows: to promote safety and soundness; guard against systemic risk that can lead to market failure; establish a competitive market and protect consumers.

\section{Regulation of financial markets}

The distinct features of financial markets, and the immediacy of the effect of a failed financial market on the economy, distinguish them from other markets (Stiglitz 1993). Moreover, as a result of the cost of regulation, such as the cost of reporting or compliance, or the costs of entry to the market and the extent to which these costs are passed on to the end customer, the rationale and objectives for financial regulation are important.

\section{Stability of financial markets}

The problem of moral hazard is particularly prevalent in financial markets where the cost of information collection is immediate and high, incentivising the agents (firms) of the principals (customers) to take hidden actions or act opportunistically. Llewellyn (1999) states that a regulationfree financial market environment imposes costs on consumers, as they are not able to ascertain the true costs of a product or its nature or the basis upon which it is offered. He suggests that the rationale for regulation in this regard is not to restrict or replace competition but in fact to enhance it by offsetting market imperfections, which may compromise consumer welfare. This concept underlies the differentiation between a micro-prudential and macro-prudential approach to regulation, where the latter is aimed at safeguarding the financial system as a whole through regulation (Hanson, Kashyap \& Stein 2011).

Staschen (2010) indicates that the key objectives of regulation in financial services are aimed at serving public interest through stabilising the financial system, on the assumption that public interest is best served through governmental interference and regulation. However, Edgar (2009), with reference to the Basel implementation in the banking sector, warns that a reasonable regulator in a financial market should guard against increasing regulation of the financial system, as it may lead to further financial exclusion through added complexity and costs.

\section{Financial inclusion}

The importance of financial inclusion has been highlighted by the G20 and World Bank (World Bank 2015) and is viewed 
as an important strategy to achieve financial growth and social development (Terzi 2015). It is defined as 'the process of ensuring access to financial services and timely and adequate credit where needed by vulnerable groups, such as weaker sections and low-income groups at affordable cost' (Kumar 2013:6).

Financial inclusion is argued to stimulate growth through a greater pooling of funds, which allows for an improved allocation thereof and reduction of poverty (Claessens 2006). The reasons for financial exclusion (De Koker \& Jentzsch 2013) can be attributed to affordability, accessibility or eligibility, with the latter referring to individual disqualification because of, for instance insufficient proof of identification. However, these reasons are put forward from the perspective of the customer. An alternative view is that lower income individuals are often perceived to be difficult to serve by suppliers, or that available products fail their needs. Further perceptions are that the risks associated with these individuals are difficult to manage and that existing regulations pose barriers to entry to the market (Aduda \& Kalunda 2012).

A recent article by Marti and Scherer (2016) explores how financial regulation may enhance social welfare. They propose that inclusive financial regulation is dependent on institutional design that includes all affected social groups. Rather than focusing on a broader technocratic regulatory approach that overemphasises stability and efficiency within the market, they build on the theory suggested by Schneiberg and Bartley (2010:34), who state that inclusionary financial regulation should not merely interfere with financial markets but should 'constitute' financial markets. Terzi (2015) explains that too much regulation or insufficient synergies are partially to blame for financial exclusion resulting from increased costs and individual disqualification. He proposes that policies in pursuit of financial inclusion should be linked to macroeconomic stability. Apart from improved information required by the regulator in terms of what Marti and Scherer (2016:313) emphasise as 'management research' of all representatives in the market, a deviation is required from the normal path that investigates how the regulator can improve stability and efficiency of those already in the market. The literature therefore shows that that both the avoidance of market failure and the realisation of improved financial inclusion should be key objectives of the regulator.

\section{Interaction between stability and financial inclusion}

The risk associated with poorer customers, such as the risk of default and of failing to sell low margin products at sufficiently high volumes, implies a trade-off between an increase in financial inclusion and market stability. Hannig and Jansen (2010:22) suggest that the question of whether an increased focus on financial inclusion can undermine the stability of a financial market is relevant, because the origin of the crisis in the subprime market at least initially suggested destabilising spillovers from the lower end of the market to the remainder of the system. Of particular concern in many developing countries is the additional regulatory uncertainty arising from the rapidly proliferating, technology-driven policy solutions that boost small-scale transactions flowing through the national payment system.

Khan (2011:12), however, states that the regulatory objectives of stability and financial inclusion are so interrelated that their coexistence is in fact mandatory. Financial inclusion results in a 'deeper, more diversified and resilient financial system as well as healthier corporate and household sectors which can enhance financial stability'. This view is supported by Prasad (2010) and Morgan and Pontines (2014), who suggest that inadequate access by small-scale entrepreneurs to credit has an adverse effect on employment and the stability of the economy.

Considering the regulatory intent to prevent market failure and instability, who should be responsible to give effect to greater financial inclusion? According to Khan (2011:13), this is a financial policy issue that forms part of the regulatory objective requiring formal financial systems to deliver 'affordable financial services with greater efficiency'. Whatever the regulatory framework and interaction between the regulator and its regulated industry, he proposes a regulatory imperative to establish greater financial literacy and awareness, with the understanding that prudential regulation remain important to ensure that these initiatives remain commensurate with the risks of greater financial inclusion. Demirgüç-Kunt (2014) states that the government has to focus on three areas to promote financial inclusion: technological innovation, to reduce transaction costs; product design, to ensure products are appropriate and affordable; and financial literacy, to ensure users understand the concepts and promote responsible uptake of products.

Kenya provides an interesting case of the balance between financial stability and financial inclusion in emerging markets that have been sought through a regulatory framework. The example of the branchless banking concept rolled out in Kenya and the innovation of M-Pesa required the regulator to revisit the concept of individual disqualification and allowed mobile banking customers to be exempt from the documentation requirements imposed by banks (DemirgüçKunt \& Klapper 2013).

\section{The political economy of regulation in the financial industry}

Considering the rationale and objectives for regulation as discussed above, the relationship between political outcomes and their effect on supply constitutes what is commonly referred to as the 'political economy' - the application of economic analysis to the study of political processes (Schnellenbach \& Schubert 2015). The concept explains how the government operates within society on the assumption that it is considered to help regulate society to reduce the impact of any economic and social crisis, as the failure thereof may lead to unstable social relations (Wan \& Bramwell 2015). At the same time government needs to maintain legitimacy, 
without which it will be unable to regulate the economy or maintain social order. In this context government has a responsibility towards social structures and therefore exhibits 'essential common elements such as formal authority and legitimacy, central decision-making and coercion' (Rosenau \& Czempiel 1992:213).

Within the context of political economy, the concept of regulatory capture should be considered, referring to a phenomenon where regulated firms gain considerable power over its regulator, and this is often more common in the context of oligopolies. This happens when the regulator oversympathises with the firms it is supposed to regulate. Staschen (2010) proposes that regulatory capture may lead to socially suboptimal shifts towards higher producer surplus at the expense of consumer surplus but points out that a degree of capture will be inevitable. What is important is the subtlety of the nature such influence may present. It may lead to or develop out of a relationship between a particular firm and the regulator whereby industry knowledge, which is vital for the regulator's effectiveness, is channelled (Boyer \& Ponce 2012). This may either lead to a sympathetic relationship towards that firm or general regulatory forbearance ('over-regulation'). The regulator must guard against becoming too enmeshed with regulated firms, allowing for their interests to be elevated beyond public interest. This is what Samarajiva (2001) refers to as 'legitimacy of a regulator' - to act and to be seen to act in the public interest - and to construct what is deemed to be in the public interest through a participatory process.

Although public interest theory assumes that government has the best interest of society at heart, it simplifies the complex political economy process, where legitimate social goals are in practice measured against the objectives of particular stakeholders (Loayza, Oviedo \& Servén 2004). Regulators may respond to business demands for many reasons, including self-interest as a result of lobbying or in an effort to protect existing business based on the importance of firms to the economy (Shaffer 2010). Considering that regulation is often shaped by policy responses, the information flow between regulators and industry in relation to their respective motives is influenced largely by the type of regulatory intervention.

The literature makes mention of certain tools that can be employed by the regulator to obtain information to close the asymmetry gap. The typical command-and-control style of regulatory intervention is stifling to business cooperation and information flows from business to the regulator (Malik 2014). Self-reporting rules, on the other hand, fit in with the 'new governance agenda' for private institutions to take the regulatory objectives on board (Etienne 2015:259). Although information flows are improved with self-reporting (in comparison to inspections or traditional command-andcontrol relationships), this is dependent on incentives to firms. One of the ways in which regulators may overcome the possible disparity in motives between themselves and their industry is to attempt to alter the motivations of regulatees. This has been referred to as 'relational signals' as a result of information exchanged in repeated interactions (Etienne 2013:33). Through repeated interactions, the regulator and regulatees learn to understand their relationship through the same lenses. Although this will not lead to alignment of the goals, they will develop a common understanding of their relationship. This helps parties to know when positive or negative signals are sent, and regulators and regulatees use these signals to interact with one another.

Van der Heijden and De Jong (2013:4) discuss the various degrees of government enforcement and private sector involvement of different regulatory regimes. Using building regulation as a context, they refer to 'enforcement strategies' to describe the tactical choices made by regulators to enforce regulation. 'Deterrence-based strategies' refer to deterring non-compliance before it has happened or instituting sanction after a rule has been broken. Compliance-based strategies are aimed at 'the spontaneous obedience of regulations', through focusing on a desire to comply as a result of moral disapproval of non-compliance. Regulatory enforcement and interaction can be categorised by government involvement with the traditional commandand-control style and complete voluntarism without government intervention at either end of the continuum. Self-regulation may include a varying degree of government intervention, which in itself leads to an ambiguous definition. It may mean, for instance, that firms control their own membership and behaviour with a certain degree of government intervention. It is this degree of intervention, directly from government or independent regulatory bodies, that leads to dissimilar characteristics of these regimes. In general, the advantages of self-regulation include expert knowledge and expertise, with easier access to relevant information. On the other hand, self-regulation may lead to accountability issues and an increase in regulatory capture. Van der Heijden and De Jong (2013) conclude that it may be easier to enforce clear rules-based regulation, as the parameters are clear. Command-and-control enforcement, however, is expensive and may not incentivise regulatees to comply with the scope of the regulation.

\section{Financial regulation within the South African context}

As a result of apartheid and the imbalance in economic power between various groups in South Africa, market competition remains imperfect and the industry is dominated by an oligopolistic structure. Although informal systems offer much wider access to financial services, the ability of individuals to compete in the formal financial market remains limited because of 'excessive regulation, lack of competition or information asymmetry between borrowers and lenders' (World Bank 2015). According to the World Bank (2015), 54\% of South African adults have access to a financial product. It finds that more than 12 million adults lack a basic bank account, normally the first basic step to financial inclusion. Furthermore, only $35 \%$ of adults 
amongst the poorest $20 \%$ of income earners have a formal account. Considering South Africa's political past, financial inclusion has gained recognition as one of the main pillars of the development agenda in South Africa and plays a vital role in the ongoing transformation and development of society.

The financial system in South Africa needs to be looked at within a political economy of high levels of poverty, inequality and unemployment. We therefore find a situation where the country's financial sector is regarded as well regulated, characterised by strong financial markets, ranking seventh out of 144 countries in financial market development but with a dichotomy referred to by Staschen (1999:40) as 'the coexistence of a modern "first world" financial sector and a large informal and semi-formal "third world" financial sector'. The inequality brought about by the racial divides and geographic differentiation of wealth resulted in an economic duality characterised by institutions and regulation associated with developed markets amidst socio-economic issues common to developing markets, such as the uneven distribution of wealth and a large degree of financial exclusion. This is a challenge for the future development of the financial sector in the country.

\section{The financial regulator in South Africa}

The principal objectives of financial regulation in South Africa are to ensure that the financial system is safe and to secure confidence in the system. The current regulatory financial architecture in South Africa allows for a distinct demarcation between the banking sector, regulated by the South African Reserve Bank (SARB) in terms of the Banks Act and SARB Act, and the non-banking sector (long- and short-term insurance, collective investments and retirement funds), regulated by the Financial Services Board (FSB). Table 1 shows the current demarcation between prudential and market conduct regulation in South Africa with the respective regulators and industries. It demonstrates the four main bodies that affect financial regulation in South Africa [the SARB, FSB, National Credit Regulator (NCR) and the National Consumer Commission (NCC)] and the respective entities that they oversee (in the cells below each heading). The FSB is an independent body appointed to oversee the non-banking financial services industry and is fully funded by the industry through fees and levies. The Minister of Finance has final authority in all financial regulation.
On 13 February 2013 the South African Regulatory Reform Steering Committee chaired by the Minister of Finance published a document entitled 'Implementing a Twin Peaks model of financial regulation in South Africa' (RSA 2013) for public comment. It encapsulated the principles contained in the original policy document, 'A safer financial sector to serve South Africa better' (RSA 2011) (commonly referred to as 'the Red Book'), which culminated in the Financial Sector Regulation Bill (RSA 2015), which was passed by parliament on 22 June 2017. The bill allows for a dual regulator in terms whereof the prudential authority for both banks and nonbanking entities will vest in the SARB to ensure the required alignment for financial soundness and institutional stability of the entire financial system. Market conduct regulation will vest with the Financial Sector Conduct Authority, which will be responsible for the strengthening of financial customer protection and promoting the integrity of financial markets, consumer education and financial inclusion. This is a significant step away from the current framework, in which both market conduct and prudential regulation are shared by the SARB, the FSB, the NCR and the NCC. The Reserve Bank will oversee financial stability within a policy framework agreed with the Minister of Finance.

The Red Book contains four cabinet-approved policy objectives:

- the need to improve market conduct;

- the need to combat financial crime;

- the need to strengthen financial stability;

- the need to widen access to financial services.

Through giving regulatory stature to the intent to strengthen financial stability while simultaneously widening access to financial services, these policy objectives have been elevated to new heights. Figure 1 illustrates the Twin Peaks model, aimed at creating a more stable financial sector, underscoring the principles of the Red Book.

One of the key issues raised in public submissions in 2013 to the then Financial Services Laws General Amendment Bill involved the issue of information exchange. The FSB's view at the time was that its mandate required information sharing specifically to protect the public and to ensure safe and fair financial services markets. It is apparent that current legislation does not prescribe when and how industry will be consulted to collaborate in finding a suitable way forward on a particular issue. The FSB's draft Code of Consultation

TABLE 1: Current financial regulatory framework.

\begin{tabular}{llll}
\hline & Prudential regulation & & \multicolumn{1}{c}{ Market conduct regulation } \\
\hline SA Reserve Bank & Financial Services Board & Financial Services Board & National Credit Regulator \\
Registrar of Banks & $\begin{array}{l}\text { Registrar of Pension Funds, } \\
\text { friendly societies, long-term } \\
\text { insurance, short-term insurance, } \\
\text { securities services, collective } \\
\text { investment schemes }\end{array}$ & $\begin{array}{l}\text { Prudential Registrar } \\
\text { Registrar of Financial Services } \\
\text { Providers }\end{array}$ & - \\
Banks & $\begin{array}{l}\text { Some non-banks (e.g. insurance } \\
\text { companies) Securities markets }\end{array}$ & $\begin{array}{l}\text { Banks } \\
\text { Non-banks } \\
\text { Securities markets }\end{array}$ & $\begin{array}{l}\text { Credit providers including banks } \\
\text { and non-banks }\end{array}$ \\
\hline
\end{tabular}

Source: Adapted from Bird 2013 


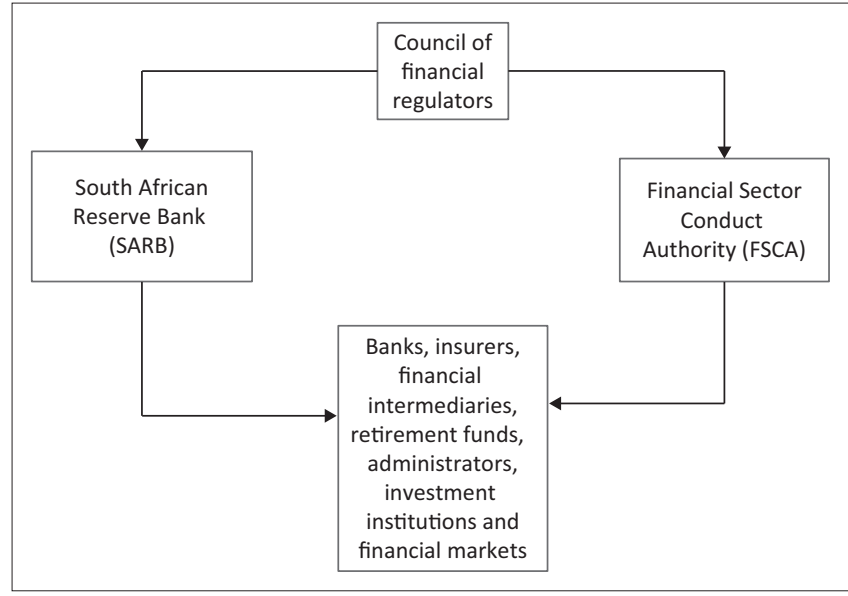

Source: Bird 2013

FIGURE 1: Future financial regulatory framework under Twin Peaks.

makes reference to the FSB's duty to consult all materially affected stakeholders on future proposals.

One key stakeholder is the Association of Savings and Investment South Africa (ASISA 2015), which acts as the industry body for the majority of South Africa's 'asset managers, collective investment scheme management companies, linked investment service providers, multimanagers and life insurance companies'. ASISA's mandate is to strengthen relationships with key stakeholders and to remain a trusted partner to these stakeholders in the financial services industry. ASISA represents its members through various standing committees and working groups. Industry representatives are appointed on these working groups and standing committees to convey their company-specific interests and influence the regulator as a combined industry. As membership to ASISA is voluntary, non-conformation to their codes, guidelines and principles is not penalised. However, membership implies agreed compliance, which makes the industry body influential as a conduit between the regulator and industry.

In concluding this section, we reiterate the particular challenges presented by South Africa's financial development, which requires a simultaneous focus on financial inclusion and consumer interests within the wider context of competitiveness and the general protection against market failure. Although the literature is clear on the objectives of regulation to enhance market stability through responsive regulation following a risk approach to institutions, regulatory policy to promote market inclusion requires a macro-prudential approach providing for effective relational signalling to its industry.

\section{Research methodology}

The research followed a qualitative approach to gain insight into the strategies of the regulator and its interaction with industry. The research was initiated through desk research to gain a greater understanding of the theoretical rationale for regulation and its objectives. The interview schedule was organised around the four major areas relevant to the research: firstly, the purpose and effect of regulation; secondly, the objective of financial inclusion; thirdly, the possible tension between the rationale for regulation and inclusion; and lastly, the interaction between the regulator and the industry. The semi-structured interviews with predetermined themes and initial questions allowed for some structure and ensured relevance.

The population consisted of the long-term insurance services industry in South Africa regulated by the FSB. Considering the vastness of financial services and in particular the nature of the regulatory framework, it would have been ideal to include respondents across all spheres of the industry, including consumers. However, to avoid embarking on a research process that might lack sufficient depth to warrant confidence and reliability, the population earmarked for the study comprised long-term insurers (LTIs) in South Africa. According to the KPMG report of 2014 the largest five LTIs in South Africa held $72 \%$ of the total market capital of the LTI industry and comprised Sanlam, Old Mutual, MMI Group Ltd, Liberty and Discovery. The sample consisted of three of these five insurers, the industry association and regulatory stakeholders.

Respondents were selected based on their seniority and experience within their particular firms or their involvement in representing their firms at the regulator or their involvement in the implementation of new regulation, as well as senior executives at the industry body (ASISA) and the regulator (FSB) (see Table 2).

Each of the interviews was recorded with permission and transcribed. Each transcript was codified through thematic analysis by applying open coding. Where more than one interview for a particular organisation was recorded, these interviews were grouped together to obtain an organisational view. The next step in the process was the identification of trends between respondents.

To ensure research credibility, various strategies were employed. Interviewees were contacted again to clarify and confirm their views and check their comments for accuracy a process of respondent validation. Triangulation was insured by testing the findings from multiple perspectives. This was achieved through the utilisation of various sources, including views from firms in the industry, the regulator and the industry body. Furthermore, the study relied on policy

TABLE 2: Profile of respondents

\begin{tabular}{ll}
\hline Organisation & Identity reference \\
\hline Insurer 1 & $\ln 1$ R1 \\
Insurer 2 & $\ln 1$ R2 \\
Insurer 2 & $\operatorname{In} 2$ R1 \\
Insurer 3 & $\operatorname{In} 3$ R1 \\
ASISA & IB1 R1 \\
ASISA & IB1 R2 \\
FSB & Reg R1 \\
FSB & Reg R2 \\
FSB & Reg R3 \\
\hline
\end{tabular}


documents and public documents to verify comments. As the research occurred within a particular context (financial services within South Africa) it cannot be stated that the findings would be relevant to all other regulatory settings. However, there may be a high degree of applicability in similar contexts, such as regulated financial services in emerging economies, where there is a need for greater financial inclusion.

\section{Research findings and discussion Financial stability and regulation}

Our respondents were not in favour of self-regulation. They explained that regulation existed because firms could not rely on each other to comply with self-enforced rules, which could result in the loss of competitive advantage and market stability. It was therefore noteworthy that respondents were in favour of a formal regulatory approach subject to the regulator's enforcement powers, as there appeared to be insufficient trust between firms to comply with self-regulation.

Those respondents familiar with the current implementation of prudential regulation under solvency and adequacy measurement recognised this as an important measure to protect the market. However, both the industry body and insurers expressed concern that an overemphasis on market stability and prudential regulation may come at the cost of the other objectives, such as consumer protection or financial inclusion. The concern was that it inadvertently detracts from the focus that is required for improved inclusion. As stated by one insurer, 'You could have an over-focus on stability, which would kill off innovation' (In2 R2-17).

The regulator explained that the issues of stability and inclusion were not separate issues, as the focus on market stability had consumer protection as its goal. The objectives of market stability and consumer protection are intrinsically linked and what may appear as the ostensible emphasis on market stability is, according to the regulator, an element of consumer protection. The regulator was of the view that the split in market conduct and prudential oversight under the Twin Peaks legislation would allow for a greater proportionality of the different objectives, including that of inclusion.

It is common cause that legislative changes come at a cost. Typically these would include system changes, resources and the general costs of having to do something additional or differently, or to refrain from doing something that previously may have resulted in profit. ASISA viewed the cost of compliance as difficult to ascertain and stated that the real figures were not known:

'I suppose I never really get actual figures, and also compliance costs are always something that's difficult to measure. Because putting a system in place you can kind of give an amount to, or resources you can kind [of] give an amount to, but not the time spent, not just by the compliance personnel but by the people that need to be trained and all the processes and procedures that go down the line'. (IB1 R2-19)
One insurer estimated their compliance bill for a certain segment of their business to be extraordinarily high, stating the following:

'Just speaking on behalf of our corporate business, which is the one that I have the oversight over currently, so that's the employee benefit space, retirement funds and value funds, etc. This year, of our total investment in projects in the business, $40 \%$ of that spent was spent purely on regulatory projects. That is a significant amount. And that's just regulation changing, where we have to update our systems, we have to do a whole lot of training, we have to spend a huge amount educating the advisor force out there and communicating to customs. And that is $40 \%$. I mean, that is significant'. (In2 R1-7)

The study showed that the two large insurers, focusing on the lower end of the insurance market specifically, shared the view that the South African financial services market was not overregulated, irrespective of the plethora of existing and planned regulation. As stated by a senior legal advisor of one insurer:

'You know, there's a general complaint that we are overregulated, but we are not over-regulated. We are not even close to being over-regulated. We are under-regulated comparative to other countries. It's pointless to have an attitude that regulation is in the way; it is better to have an attitude, 'Regulation is here; let's use it as an advantage'. (In2 R2-100)

This was confirmed by a senior insurance executive, who stated, 'we don't operate in a ridiculously onerous compliance environment, maybe in the financial advice space a bit, but in the financial advice space I kind of feel like it's necessary' (In1 R1-31).

Irrespective of the general belief that the industry was not over-regulated, the current cost of compliance was still perceived to be a barrier to market entry. One of the concerns expressed at the entry level of the market was that the regulatory requirements were out of sync with the real risk the industry was exposed to at this level:

'I think compliance is necessary, I think it should be embedded. It is not the cost of compliance that I'm worried about; it's the cost of inappropriate compliance that I am worried about, this wallpapered compliance, where we think that people money launder at R100 a month'. (In2 R1-29)

The sentiment that the high cost of compliance was a barrier to financial inclusion was summarised as follows by one insurer:

'In rand terms the cost of compliance is just the same as everyone else. But the actual cost of compliance isn't [in] rand terms. The cost of compliance is that the regulations are not designed for the market; they are designed for a sophisticated market'. (In2 R2-27)

The insurers confirmed that compliance requirements were often imposed for customer protection but that the current focus did not allow for increased financial inclusion:

\footnotetext{
'The greater your customer protection, the higher your barrier to entry. The higher the barrier to entry, the more the person who gets into the system needs money to survive; that means they all go for the top end of the market because that's where the money is'. (In2 R2-67)
} 


\section{Regulation and access to the market}

The regulator's view, as a starting point, was that its primary role in relation to greater financial access was to create an environment conducive to financial inclusion. It did not see its role as establishing markets but rather that it needed to ensure that regulation did not promote unintended barriers for the financially excluded to enter the market

However, the industry argued that the regulator was not meeting its mandate to create a regulatory framework or an enabling environment at the lower end of the market. Two of the major insurers and the industry body alluded to an alternative paradigm required to meet the needs of those who currently found themselves excluded from the financial services sector. They suggested that financial inclusion in South Africa required an overhaul of existing structures, processes and definitions to cater for those at the fringes of financial inclusion, rather than attempting to utilise the mainstream understanding of sophisticated financial services:

'I still everyday see us re-treading upper market constructs into the emerging market. There is very little knowledge and understanding of the informal financial instruments that operate in the market. And where we do notice them, we immediately jump towards trying to formalise them. We are stuck in our definition of what a financial product should look like and it is largely Western, upper market-driven constructs'. (In2 R1-49)

A common theme arising from the coded interviews was related to insurers stating that it was the expressed intention of the regulator to set an enabling environment for inclusion that the industry was not seeing in practice. Responses reflected that both the industry body and insurers appeared to detect reluctance on the part of the regulator to facilitate the required conversation in this regard. As stated by the insurance body:

'From the sort of lower income market side, we have been trying to engage with the FSB for a long time and they don't seem that interested. They are just not very open to ... they said there's been a lot of conflict with the industry saying everything you're putting in place is first world, and you've got first world markets and third world markets in South Africa and you're not looking at the reality of the situation, we don't have the data, we don't have this, we don't have that, you're just being insistent that you have to have it. So there's that tension and the regulator doesn't seem to be open to talk about what practical steps can be taken'. (IB1 R2-67)

One of the respondents focusing solely on the lower end of the market stated:

Trying to apply middle market regulation to entry level market products - now you must try and find someone in the rural areas with a CFA ... the regulator's role should be to remove barriers'. (In1 R1-46)

The responses showed recognition that the trust relationship between firms in the industry and the regulator had improved. However, these firms did not feel empowered to explore solutions outside the realm of what they were currently offering, in fear of regulatory reproach:

'Part of that cost issue is regulation, which means that you can't change the structure of the product or the way it's offered because regulation constrains it. It's not all regulation's fault; there are also legal constraints which are not regulatory, common law constraints, which can't easily be changed. But mostly we are incentivised, because that's the market, the problem is that you can't get there that easily. There's a certain amount of regulation risk that you have to take and pilots would help. It would make it easier if there was a recognised ... almost like a recognised area where you can try something out, making the way the product rules work comply with the principle that the regulation is trying to get you and not the actual physical regulation itself'. (In2 R2-46)

The respondents supported the idea of a platform for all stakeholders to participate in experimenting with solutions. This implied a platform with lighter touch compliance. It would allow for 'cheaper' products designed in novel ways, bundled into innovative solutions or taken to the market in different ways. There was very little incentive for industry to embark on something like this without the support of the regulator because they feared regulatory contempt and these pilots could be very expensive for a firm to run. Furthermore, considering the constraints of competition regulation, the role of the industry body to ensure that firms were not colluding but presented a solution that would be beneficial for the market in general was important. The need to overcome the current constraints laid down by the Competition Commission in allowing industry to find novel solutions was highlighted. The regulator indicated that there may be a need for developing incubators to experiment with appropriate products with a lighter compliance touch, stating:

\begin{abstract}
'... some of the stuff that's being talked about internationally is allowing for a formal framework for pilots and piloting particular products or business models ... It's very early days, but I think if one is talking about how we take inclusion forward in a way that allows for innovation and experimentation, but in a more controlled environment. Not controlled in the sense that it's prohibited, but it's allowed in an incubation phase that is subject to more intensive oversight'. (Reg R1-43)
\end{abstract}

\section{Inclusion and market stability}

Responses indicated that there is a potential tension between the regulatory objectives of financial inclusion and market stability but that it is possible to allow for both objectives simultaneously. There is an understanding that greater inclusion would by its very nature expand the risk associated with including those who up to this point have not been able to afford financial products. The view was expressed that the answer lies within being responsible when allowing for greater financial access and that the emphasis should be on obtaining the right balance between including those that are currently excluded but not to the extent that it allows for market abuse:

'I think it's not really financial inclusion if people are being taken advantage of. So giving someone a loan they can't afford to repay is not financial inclusion; that's abuse. So, I don't think it 
comes at a cost of financial inclusion. So for example, some of the most recent caps on interest rates for loans are going to exclude people. Now I think they've gone too far; I don't think they're going to implement it, I think it's an opening gambit. So, it's an easy example, but getting that cap right is a really important thing because if you put it too low then you create exclusion; if you put it too high you leave yourself open to abuse. So, it's to find that balance where you protect the people enough without excluding them because of the way you're protecting them'. (In 1 R1-76)

It therefore requires an approach amenable to establishing the real needs of people at the fringes of society. The industry body stated that the answer to dealing with this tension was not divorced from the issue of trust referred to earlier:

\begin{abstract}
'If we are going to give you access, how do we know that you are not going to abuse it? And in the entry level market I think it's a very heightened concern. Because there's asymmetry and because it's the most vulnerable people. And these are the people that look to the state and have the greatest expectation, rightly so, that the state will protect them. So I think it's that kind of imperative from the regulator'. (IB1 R1-92)
\end{abstract}

One of the regulator respondents stated that one should not view stability and inclusion as conflicting, although she stated that even though the concepts were related, it was imperative to consider their impact separately. Thus all the respondents acknowledged the importance of inclusion but that greater access should be underpinned by responsibility.

\section{Information transfer between firms and the regulator}

An important antecedent to the objectives of market stability and financial inclusion is the regulator holding high quality information about the industry. Much of the information relayed to the regulator is through the process of reporting, which typically involves insurers providing specific information in terms of prescribed requirements or set questions. The regulator recently introduced what it called 'thematic reviews', referring to onsite visits to discuss specific topics or trends that it picks up from the industry, which it believed was a step forward to obtaining better information to inform their regulatory focus.

All of the insurer respondents concurred that effective information transfer required upfront engagement that surpassed the typical mandatory reporting. Insurers proposed a process for which they play an integral part of the framing of the issue. In relation to greater financial access, for instance insurers were concerned that the regulator would attempt to frame the issue in isolation, which ultimately steered the solution in a particular direction:

'I think it would be nice if we went through a process of framing the problem. So if the regulator sees a problem, the first discourse I'd like is, do we also see a problem? Can we at least together agree that there is a problem, what is the problem and to name it together?'. (In2 R1-13)
There was a concern that, although the regulator focused on data, it might not understand the context, as it did not ask the right questions:

'They've got plenty of data. What I don't know is whether they've got information or insights because I don't think that that data can turn into information or insights without an interactive conversation. You need to have a discourse. If I send you data, you can look at it, you can process it, but in order for you to achieve insights you need to ask me questions, we need to talk. You need to ask 'why' questions, not 'what' questions. We get lots of 'what' questions'. (In2 R2-88)

The question then arises whether the industry body should not take up this responsibility. The problem with this proposal is that ASISA collates views and often provides a moderated or so-called industry view to the regulator. One possible solution to the issue is for the industry to drive the framework and engage the regulator, which is the opposite of what is currently happening. The proposal by one of the respondents is the following:

'More than anything else business wants certainty. Bad certainty or good certainty doesn't matter, we want certainty. So if you came as a regulator and said, 'we've been talking about microinsurance. It's actually stalled for four years now. Do you want to get this thing going?', industry through ASISA will say, 'we'll fund a 2-year project, we'll pay for it. We'll second people to you to work in National Treasury for 2 years to deliver a microinsurance or an access framework. We'll pay for it. You've got to sign off on it so you will have the final veto on it, but we'll pay for it. Because that gives us certainty and that's the most precious commodity for business'. (IB1 R1-110)

The regulator confirmed that under Twin Peaks collaboration with industry is indeed high on its agenda.

It was noteworthy that there appeared to be general recognition that the degree of trust between the regulator and firms in the industry had improved but still required further attention. As stated by one insurer:

'Industry is suspicious of the regulator. They are viewed (not surprisingly because they are the regulator, after all) as bad news. If they ask you a question you give it to them, but you give it to them because you have to. If we could trust the regulator and if we didn't have things to hide then your information would probably flow more easily. But we have things to hide and the reason we have things to hide is because we do things wrong, but the reason why we have things to hide is because the regulation is either being ignored as a matter of course, one. Two, it's inappropriate and is therefore being ignored because you can't function with it to make your business work. Three, it's being ignored because the regulator is ineffective'. (In2 R2-92)

This was echoed elsewhere by the industry body, where it states with reference to the FSB:

'I don't want to give you data because if I give you the data you're going to come after me. So I think the question about data and which comes first: There isn't data at the moment that allows anybody to form a real picture of what's happening at a kind of inclusion space ... So I'm not seeing how you're going to get a consolidated picture'. (IB1 R1-104) 
Although not surprising considering the enforcement powers of the regulator, insufficient trust of the industry to engage the regulator on data that may assist with greater financial inclusion is a common concern.

The responses showed that traditional rule-based legislation might not be ideal to give effect to the policy of increased financial inclusion and that outcomes-based regulation could be more suitable. Hereby the action of the insurer is ultimately measured against the outcome it is supposed to achieve. Typically the regulation would define the regulator's intent and contextualise it in terms of the industry. Where applicable this may be supplemented with traditional rules. One of the respondents from the regulator stated that:

'The one thing that we got from the financial crisis is that the whole self-regulatory, light-touch approach was a failure. But on the other hand, the other end of the spectrum is also a complete failure. A complete regulatory, rules-based, compliance-based approach is also disastrous. So what the conversation has been and the reformed direction that we've been trying to communicate is saying is that we need to shift to something which is in a sense more balanced and we don't talk about principles-based versus rules-based anymore ... We are moving towards an outcomesfocused approach to regulation, which has an appropriate balance of principles and rules that in combination allow you to achieve the outcomes that you want to achieve'. (Reg R1-10)

This view was aligned with international experience, such as in the United Kingdom, where the FSA promulgated outcomes-based regulation, requiring firms to show that they achieved these outcomes after a certain point in time. Firms may then define for themselves the most appropriate route to reach the particular outcome, considering their market. This was highlighted by another respondent from the regulator:

'So in an outcomes-based approach one has a little bit more flexibility on how one wants to apply the concept of proportionality. So depending on the nature, scale and complexity of the business you may apply the requirements slightly differently. With rules the drawback is: whether you are small or big, whether you have high risk or not, that is what you need to apply with. So I think from an outcomes-based perspective, it could contribute to faster and greater financial inclusion because in principle, each person can apply his own judgement to make sure that there is consistency in the application'. (Reg R2-63)

\section{Conclusion}

The results support the views of Dewing and Russell (2004) that regulations in financial services are necessary to prevent market failure but may result in a proliferation of complex rules, possibly resulting in overshooting by the regulator, which in turn may cause instability of the market and pose barriers to entry. The findings show that there is a potential tension between the regulatory objectives of market stability and financial inclusion and that a disproportionate focus on either objective could adversely affect the other.

The research supports a consultative process requiring of industry to create a multi-stakeholder platform to facilitate exploring the uniqueness of the base of the pyramid to discover opportunities for cross-sector collaboration between the private and public sector to design innovative solutions. It also highlights the requirement for firms to collaborate with the regulator and each other via ASISA, to ensure that they are able to influence government to create policies that promote greater financial inclusion supported by outcomesbased regulation. Considering that policy is driven at national level, data should be shared between the private and public sector, relying on ASISA to collate information and the FSB to facilitate the discussion. The results indicate a tendency on the part of industry to wait for regulatory signals, rather than proactively influencing government policy. This may be a product of the structure and mandate of the regulator and industry body and historic relationships between the regulator and industry. The results further reflect the need for industry, the regulator and government to co-frame issues rather than being obliged to rely on the FSB to draft regulation in isolation.

We argue that the entry level market may require a different paradigm to 'usual' insurance constructs. These constructs typically refer to products, structures and processes designed for the middle- to upper-income markets, which are at times inappropriate for the entry level market.

We conclude with a framework reflecting contextual factors that may influence the propensity of a regulator to expand its focus from its traditional constituency to include consumers who are excluded from regulatory provision, with practical implications for industry and policymakers (see Figure 2).

The block at the bottom left of Figure 2 indicates factors that may impact negatively on the propensity or willingness of

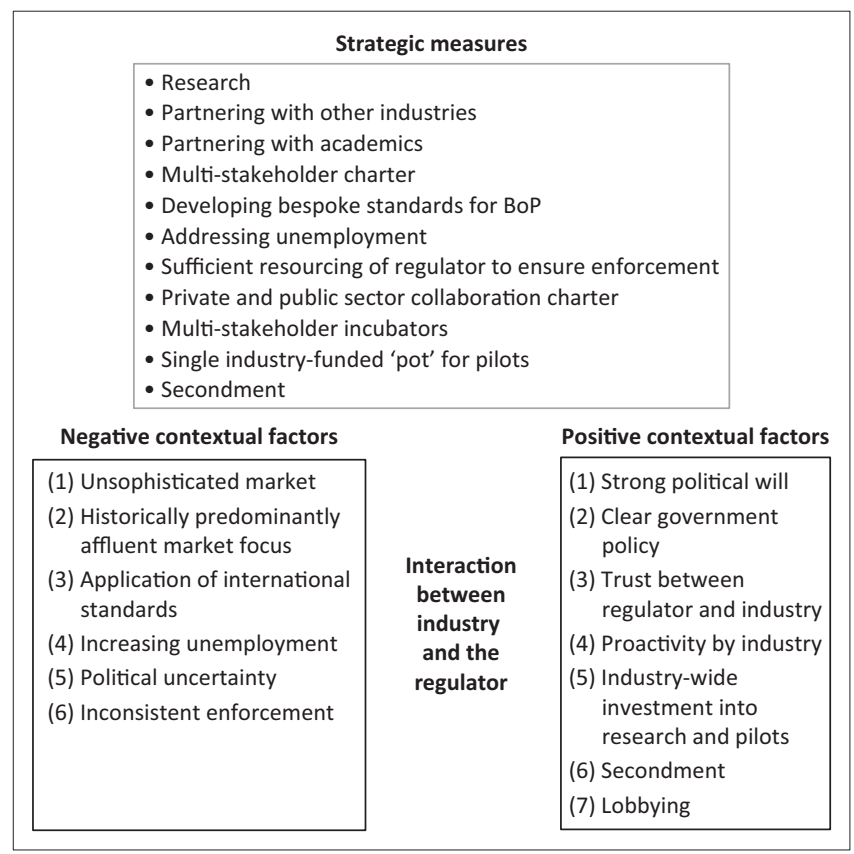

FIGURE 2: Conceptual framework of the interaction between industry and the regulator. 
the regulator to include consumers whose interests are not included in the regulatory focus. For instance, the gap between the regulator's current market focus and the nature of the segment of the market that is currently excluded is relevant in this regard. Both the literature and results mentioned political uncertainty as a contextual factor, as it may possibly detract from the effectiveness of the government policy to increase inclusion. This refers to the general sociopolitical state of the country with the premise that a more unsettled and distrusting industry may show less propensity to engage the regulator (or government) to consider inclusion of those who have been excluded.

The block at the bottom right of Figure 2 refers to factors that may accommodate greater interaction between the regulator and industry to include those who are peripheral to the current regulatory focus. The data showed that a proactive stance by industry is a positive contextual factor, accommodating inclusion. The extent to which the industry demonstrates an appetite to expand its focus to previously excluded or unregulated consumers within a market may influence the degree to which the industry and the regulator collaborate more effectively on the matter. Proactivity of the industry appears to be an important contributing factor, especially where the regulator does not take the initiative to give effect to the policy through practical and visible projects. This proactivity may be demonstrated through industryfunded incubators, allowing for research of a sample of the market for experimental purposes. This must be conditional to complete and transparent regulatory oversight. To ensure compliance with competition regulation, these incubators or pilot exercises must be facilitated by the industry body and be representative of multiple firms to avoid the independence of the regulator being compromised. A further positive contextual factor lies in the ability and willingness of the regulator and industry to promote the effective information flow between each other, such as through secondment of employees. This will assist with the quality of information held by both firms and the regulator of each other and assist with engagement between them without compromising the independence of the regulator.

The top column of Figure 2 refers to the strategic measures that should be considered to improve the effectiveness of the collaboration between the various stakeholders to increase market inclusion and results in practical implications for the industry and policymakers. In essence, a multi-stakeholder charter is required that explicitly states the objectives of the stakeholders from which standards for the excluded market may be developed. The collaboration between the private and public sectors will contribute to the efficiency of government policy to facilitate regulatory inclusion. Research and the development of appropriate standards and regulation are resource-intensive operations. It is therefore imperative that the regulator have sufficient resources with the required experience and skill. Secondment of staff between the industry and the regulator, or appropriate internships and training, will assist in addressing this issue. Furthermore, pilot exercises could be conducted, utilising the information acquired through research. This may allow the industry to test-run products and processes subject to a less restrictive or rigorous regulatory process. This may be done in an effort to ascertain the appropriateness of the planned interventions, the cost implications for the industry and the time horizon to give effect to the policy.

The study is limited by its qualitative nature and is exploratory in purpose. Future quantitative research into the actual cost of compliance would better indicate the full effect of regulation on the industry and the implications thereof in relation to financial exclusion. Furthermore, a comparative study of the interaction between the regulator and the industry in emerging markets with sophisticated regulation and 'unsophisticated' consumers is proposed.

\section{Acknowledgements Competing interests}

The authors declare that they have no financial or personal relationships which may have inappropriately influenced them in writing this article.

\section{Authors' contributions}

Both authors contributed towards the writing of this article.

\section{References}

Aduda, J. \& Kalunda, E., 2012, 'Financial inclusion and financial sector stability with reference to Kenya: A review of literature', Journal of Applied Finance \& Banking 2(6), 95-120.

Association for Savings and Investment South Africa ASISA, 2015, viewed 27 May 2015, from http://asisa.org.za/en/

Basso, L.J., Figueroa, N. \& Vásquez, J., 2016, Monopoly regulation under asymmetric information: Prices vs. Quantities (SSRN Working Paper July 29, 2016), viewed 09 October 2015, from https://ssrn.com/abstract=2632941

Bird, G., 2013, Twin Peaks: Regulation - has it gone too far? viewed 09 October 2015 from http://www.mondaq.com/southafrica/x/268104/Financial+Services/Twin+ Peaks+Regulation+Has+It+Gone+Too+Far

Boyer, P.C. \& Ponce, J., 2012, 'Regulatory capture and banking supervision reform', Journal of Financial Stability 8(3), 206-217. https://doi.org/10.1016/j.jfs.2011. 07.002

Claessens, S., 2006, 'Access to financial services: A review of the issues and public policy objectives', The World Bank Research Observer 21(2), 207-240. https://doi. org/10.1093/wbro/lkl004

De Koker, L. \& Jentzsch, N., 2013, 'Financial inclusion and financial integrity: Aligned incentives?', World Development 44, 267-280. https://doi.org/10.1016/j. worlddev.2012.11.002

Demirgüç-Kunt, A., 2014, 'Presidential address: Financial inclusion', Atlantic Economic Journal 42(4), 349-356. https://doi.org/10.1007/s11293-014-9429-z

Demirgüç-Kunt, A. \& Klapper, L., 2013, 'Measuring financial inclusion: Explaining variation in use of financial services across and within countries', Brookings Papers on Economic Activity Spring, 279-340. https://doi.org/10.1353/eca.2013.0002

Dewing, I.P. \& Russell, P.O., 2004, 'Regulation of UK corporate governance: Lessons from accounting, audit and financial services', Corporate Governance: An International Review 12(1), 107-115. https://doi.org/10.1111/j.1467-8683.2004.00347.x

Edgar, R.J., 2009, 'The future of financial regulation: Lessons from the global financial crisis', Australian Economic Review 42(4), 470-476. https://doi.org/10.1111/j. 1467-8462.2009.00567.x

Etienne, J., 2010, The impact of regulatory policy on individual behaviour: A goal framing theory approach, Working Paper No. 59, London School of Economics and Political Science, viewed 09 October 2015, from http://www.Ise.ac.uk/accounting/ CARR/pdf/DPs/Disspaper59.pdf

Etienne, J., 2013, 'Ambiguity and relational signals in regulator-regulatee relationships', Regulation \& Governance $7(1), 30-47$. https://doi.org/10.1111/ j.1748-5991.2012.01160.x

Etienne, J., 2015, 'The politics of detection in business regulation', Journal of Public Administration Research and Theory 25(1), 257-284. https://doi.org/10.1093/ jopart/muu018 
Hannig, A. \& Jansen, S., 2010, Financial inclusion and financial stability: Current policy issues, Working Paper No. 259, Asian Development Bank Institute, viewed 09 issues, Working Paper No. 259, Asian Development Bank Institute, viewed 09
October 2015, from http://www.adb.org/sites/default/files/publication/156114/ adbi-wp259.pdf

Hanson, S.G., Kashyap, A.K. \& Stein, J.C., 2011, 'A macroprudential approach to financial regulation', Journal of Economic Perspectives 25(1), 3-28. https://doi. org/10.1257/jep.25.1.3

Kearney, J.D. \& Merrill, T.W., 1998, 'The great transformation of regulated industries law', Columbia Law Review 98(6), 1323-1409. https://doi.org/10.2307/ 1123301

Khan, H.R., 2011, Financial inclusion and financial stability: Are they two sides of the same coin? Speech at BANCON organized by the Indian Bankers Association and Indian Overseas Bank, Chennai, viewed 04 November 2011, http://www.bis.org/ review/r111229f.pdf

KPMG, 2014, South African Insurance Industry, viewed 06 June 2015, from https:// www.kpmg.com/ZA/en/IssuesAndInsights/ArticlesPublications/FinancialServices

Kumar, N., 2013, 'Financial inclusion and its determinants: Evidence from India', Journal of Financial Economic Policy 5(1), 4-19. https://doi.org/10.1108/ 17576381311317754

Laffont, J.J. \& Martimort, D., 2009, The theory of incentives: The principal-agent model, Princeton University Press, Princeton, NJ.

Llewellyn, D., 1999, The economic rationale for financial regulation, Financial Services Authority, London.

Loayza, N., Oviedo, A.M. \& Servén, L., 2004, Regulation and macroeconomic performance. World Bank Policy Research, Working Paper No.3469, World Bank Group, viewed 09 October 2015, from http://elibrary.worldbank.org/doi/ abs/10.1596/1813-9450-3469

Malik, A.S., 2014, 'The desirability of forgiveness in regulatory enforcement', Journa of Regulatory Economics 46(1), 1-22. https://doi.org/10.1007/s11149-0149254-y

Marti, E. \& Scherer, A.G., 2016, 'Financial regulation and social welfare: The critical contribution of management theory', Academy of Management Review 41(2) 298-323. https://doi.org/10.5465/amr.2013.0469

Morgan, P. \& Pontines, V., 2014, Financial stability and financial inclusion, Working Paper No 488, Asian Development Bank Institute, viewed from http://www.adb. org/sites/default/files/publication/156343/adbi-wp488.pdf

Pistor, K., 2012, On the theoretical foundations for regulating financial markets, Working Paper No. 12-304, Columbia Public Law Research, viewed 09 October 2015, from http://papers.ssrn.com/sol3/papers.cfm?abstract_id=2113675

Prasad, E.S., 2010, Financial sector regulation and reforms in emerging markets: An overview, Working Paper No. 16428, National Bureau of Economic Research, viewed 09 October 2015, from http://www.nber.org/papers/w16428
Rosenau, J.N. \& Czempiel, E.O., 1992, Governance without government: Order and change in world politics, Cambridge University Press, Cambridge.

RSA, 2011, A safer financial sector to serve South Africa better, National Treasury, Pretoria, pp. 1-93.

RSA, 2013, Implementing a twin peaks model of financial regulation in South Africa, Financial Services Board, published by the Financial Regulatory Reform Steering Committee, Pretoria, pp. 1-77.

RSA, 2015, Financial Sector Regulation Bill, Published by the Minister of Finance, Pretoria, B 34D-2015, pp. 1-284.

Samarajiva, R., 2001, Regulating in an imperfect world: Building independence through legitimacy. info, 3(5), 363-368.

Schneiberg, M. \& Bartley, T., 2010, 'Regulating or redesigning finance? Market architectures, normal accidents, and dilemmas of regulatory reform', in M. Lounsbury \& P. Hirsch (eds.), Markets on trial: The economic sociology of the U.S. financial crisis: Part A, pp. 281-308, Emerald Group Publishing Limited, Bingley.

Schnellenbach, J. \& Schubert, C., 2015, 'Behavioral political economy: A survey', European Journal of Political Economy 40, 395-417. https://doi.org/10.1016/j. ejpoleco.2015.05.002

Shaffer, G.C., 2010, 'Law and business', in D. Coen, W. Grant \& G. Wilson (eds.), The Oxford handbook of business and government, pp. 61-88, Oxford University Press, Oxford.

Staschen, S., 1999, Regulation and supervision of microfinance institutions: State of knowledge, GTZ, Eschborn.

Staschen, S., 2010, 'Regulatory impact assessment in microfinance: A theoretical framework and its application to Uganda', Doctoral dissertation, LSE Theses, viewed 09 October 2015, from http://etheses.Ise.ac.uk/806/

Stiglitz, J.E., 1993, 'The role of the state in financial markets', in M. Bruno \& B. Pleskosvic (eds.), Proceedings of the World Bank annual conference on development economics, pp. 19-52, World Bank, Washington, DC.

Terzi, N., 2015, 'Financial inclusion and Turkey', Academic Journal of Interdisciplinary Studies 4(1), 269. https://doi.org/10.5901/ajis.2015.v4n1s2p269

Van der Heijden, J. \& De Jong, J., 2013, 'Towards a better understanding of building regulation', Environment and Planning 36(6), 1038-1052. https://doi.org/ $10.1068 / \mathrm{b} 34120$

Veal, G.J. \& Mouzas, S., 2011, 'Changing the rules of the game: Business responses to new regulation', Industrial Marketing Management 40(2), 290-300. https://doi. org/10.1016/j.indmarman.2010.09.016

Wan, Y.K. \& Bramwell, B., 2015, 'Political economy and the emergence of a hybrid mode of governance of tourism planning', Tourism Management 50, 316-327. https://doi.org/10.1016/j.tourman.2015.03.010

World Bank, 2015, The global financial inclusion (Global Index) database, viewed 18 June 2015, from http://data.worldbank.org/data-catalog/financial_inclusion 